\title{
МАТЕМАТИЧНЕ МОДЕЛЮВАННЯ I ПРОГНОЗУВАННЯ ЗАХВОРЮВАНОСТІ НА РОТАВІРУСНУ ІНФЕКЦІЮ СЕРЕД ДІТЕЙ ДО П'ЯТИ РОКІВ В УКРАЇНІ
}

\author{
С. О. Соловйов, І. О. Терещенко, І. В. Дзюблик \\ Національна медична академія післядипломної освіти імені П. А. Шупика, \\ Національний технічний університет України "Київський політехнічний інститут"
}

3 використанням даних клініко-лабораторних спостережень епідемічного процесу ротавірусної інфекції серед дітей до 5 років в Україні було розроблено систему диференціальних рівнянь, що описує динаміку захворюваності на основі моделі Барояна- Рвачова. Модель виявилась адекватною реальним даним спостережень за інфекцією та ілюструє розподіл випадків захворювання за окремими віковими групами та залежно від кількості попередньо перенесених випадків захворювання. Модель може бути використана в подальшому для вивчення впливу різних факторів, в тому числі і вакцинації, на захворюваність ротавірусною інфекцією.

Ключові слова: ротавірусна інфекція, епідемічний процес, модель Барояна-Рвачова.

\section{МАТЕМАТИЧЕСКОЕ МОДЕЛИРОВАНИЕ И ПРОГНОЗИРОВАНИЕ ЗАБОЛЕВАЕМОСТИ РОТАВИРУСНОЙ ИНФЕКЦИЕЙ СРЕДИ ДЕТЕЙ ДО ПЯТИ ЛЕТ В УКРАИНЕ}

\begin{abstract}
С. А. Соловьев, И. А. Терещенко, И. В. Дзюблик
Национальная медицинская академия последипломного образования

имени П. А. Шупика,

Национальный технический университет Украины "Киевский политехнический институт"

С использованием данных клинико-лабораторных наблюдений эпидемического процесса ротавирусной инфекции среди детей до 5 лет в Украине была разработана система дифференциальных уравнений, описывающая динамику заболеваемости на основе модели Барояна-Рвачова. Модель оказалась адекватной реальным данным наблюдений за инфекцией и иллюстрирует распределение случаев заболевания по отдельным возрастным группам и в зависимости от количества предварительно перенесенных случаев заболевания. Модель может быть использована в дальнейшем для изучения влияния различных факторов, в том числе и вакцинации, на заболеваемость ротавирусной инфекцией.
\end{abstract}

Ключевые слова: ротавирусная инфекция, эпидемический процесс, модель Барояна-Рвачова.

\section{MATHEMATICAL MODELING AND FORECASTING OF ROTAVIRUS CAUSED MORBIDITY AMONG CHILDREN UNDER FIVE YEAR IN UKRAINE}

\author{
S. O. Solovyov, I. O. Tereshchenko, I. V. Dzyublyk \\ National Medical Academy of Post-Graduate Education by P. L. Shupyk, \\ National Technical University of Ukraine "Kyiv Polytechnic Institute"
}

\begin{abstract}
Using data of clinical and laboratory observations of the epidemic process of rotavirus infection among children under 5 years in Ukraine it was developed the system of differential equations describing the dynamics of morbidity on the basis of the Baroyan-Rvachov model. The model was adequate to the real observational data for infection, and illustrates the distribution of cases for individual age groups and depending on the number of previously cases of disease. The model could be used to study the influence of various factors on the morbidity of rotavirus infection, including vaccination.
\end{abstract}

Key words: rotavirus infection, epidemic process, Baroyan-Rvachov model.

Вступ. Сьогодні математичне моделювання епідемічного процесу інфекцій стає оптимальним засобом отримання випереджаючої інформації про (c) С. О. Соловйов, І. О. Терещенко, І. В. Дзюблик швидкість поширення інфекцій та прогнозування масштабів епідемій. Моделюванню кишкових інфекцій присвячені роботи Б. І.Марченко [1], В. В. Мефодіє- 
ва [2] та ін. Створена математична модель епідемічного процесу дизентерії Зонне на основі сильного статистичного зв'язку між рівнем захворюваності та метеорологічними факторами [3]. Ці фактори несуть найбільшу прогностичну інформацію про можливий розвиток епідемічного процесу. Проте зазначені методи дозволяють скласти тільки короткостроковий прогноз. В. П. Сергієв і В. А. Ніконова [4] з метою прогнозування захворюваності на черевний тиф застосували екстраполяційний метод - вирівнювання динамічних рядів за експоненціальною функцією. Однак в цьому випадку при прогнозуванні не враховується зміна факторів, які впливають на захворюваність.

Найбільш відомим у вітчизняних колах $є$ метод моделювання епідемічного процесу інфекцій, заснований на використанні диференціальних рівнянь $[5,6]$. У цих моделях динаміка поширення захворювання описується системою диференціальних рівнянь, в якості шуканих функцій в яких виступають кількість хворих і здорових людей на певній території. Розв'язком такої системи рівнянь $є$ рівень інфекційної захворюваності в кожен момент модельного часу. Ця методологія була розроблена в 70-і роки в СРСР акад. О. В. Барояном і проф. Л. А. Рвачовим [7-9]. Для їі створення використовувався метод наукової аналогії у відображенні епідемічного процесу - процес «перенесення» збудника інфекції від хворих до здорових 3 процесом «перенесення» матерії (енергії, імпульсу та ін.) в рівняннях математичної фізики.

Наша робота є продовженням досліджень проблем ротавірусної інфекції (PBI) та ефективності протиротавірусних вакцин в Україні $[10,11]$. Тому метою цієї роботи став аналіз епідемічного процесу РВI серед дітей в Україні за даними власних клініко-лабораторних спостережень на основі моделі Барояна-Рвачова.

\section{Побудова моделі}

У моделі Барояна-Рвачова і в більшості інших моделей такого типу вся популяція на певній території ділиться зазвичай на три групи людей:

- Susceptible (S) - здорові особи, сприйнятливі до захворювання;

- Infectious (I) - інфіковані хворі особи;
- Recovered (R) - особи, що видужали після захворювання і до нього не сприйнятливі.

При моделюванні динаміки епідемічного процесу PBI припускається, що загальна чисельність населення $\mathrm{N}$ є сталою. Таким чином, ми ігноруємо ускладнення, які можуть виникнути в результаті нових народжень або іміграції населення. ХХоча більш складні моделі можуть враховувати ці фактори, наше припущення на часі $є$ цілком слушним. Також припускається, що у досліджуваній популяції відбуваються рівномірні перемішування і особи в однаковій мірі взаємодіють між собою. Це означає, що всі здорові особи постають перед тими ж ризиками зараження, що й ті, хто вже $є$ інфікованими. Для побудови моделі, залежної від часу $\mathrm{t}$ дитяче населення до п'яти років $N$ поділяється на три категорії:

$\mathrm{S}$ : діти, сприйнятливі до PBI, які можуть захворіти, але в даний час не є інфікованими;

I: діти, які є інфікованими (хворими) і в даний час $є$ епідемічно значущими;

$\mathrm{R}$ : діти, які одужали і отримали тимчасовий імунний захист, або померли.

Оскільки кількість населення є сталою, то: $S_{t}+I_{t}+R_{t}=N$ для усіх $t$

Найпростіша модель епідемії (SIR) використовує три зазначені вище класи осіб. У цій моделі SIR члени популяції знаходяться в одному з трьох класів у наступному порядку: сприйнятливі особи залишаються здоровими або стають інфікованими; інфіковані особи перебувають на різних стадіях інфекційного процесу до остаточного видужання, а особи, що одужали, набувають імунного захисту після перенесеного захворювання на РВI. Схематично модель має наступний вигляд:

\section{Сприйнятливі > Інфіковані (Хворі) > Реконва- лесценти}

Грунтуючись на цих припущеннях нами була розроблена детермінована модель динаміки епідемічного процесу PBI на основі ступеня сприйнятливості до повторного інфікування при відомих особливостях перебігу захворювання на РВІ. Модель описана системою диференціальних рівнянь першого порядку (2).

$$
\begin{aligned}
& \frac{d S_{1 i}}{d t}=b-\lambda_{i} S_{1 i}-\delta S_{1 i}, i=1 \\
& \frac{d S_{1 i}}{d t}=\delta S_{1(i-1)}-\lambda_{i} S_{1 i}-\delta S_{1 i}, i=2-6 \\
& \frac{d I_{n i}}{d t}=\lambda_{i} S_{n i}-\gamma I_{n i}-\delta I_{n i}+\delta I_{n(i-1)}, n=1-4, i=1-6
\end{aligned}
$$




$$
\begin{aligned}
& \frac{d S_{n i}}{d t}=\alpha_{(n-1)} \gamma I_{(n-1) i}-\lambda_{i} S_{n i}-\delta S_{n i}+\delta S_{n(i-1)}, n=2-3, i=1-6 \\
& \frac{d S_{4 i}}{d t}=\omega_{1} R_{i}+\alpha_{3} \gamma I_{3 i}-\lambda_{i} S_{4 i}-\delta S_{4 i}+\delta S_{4(i-1)}, i=1-6
\end{aligned}
$$

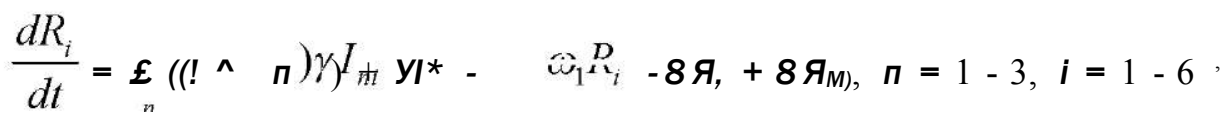

де $i$ - вікова група (<1 року, 1 рік, 2 роки, 3 роки, 4 роки, 5 років);

$b_{n i}(i)$ - група сприйнятливих дітей до п-го випадку захворювання на РВІ у віковій групі i;

$1_{n i}(i)$ - група дітей, інфікованих п-им випадком захворювання на РВІ у віковій групі i;
Я. - група дітей, що одужали та є імунними після перенесеного захворювання у віковій групі i.

$1(i)$ - ймовірність інфікування у віковій групі $i$.

Інші параметри та їх значення показані в таблиці 1.

В моделі використані ключові особливості епідемічного процесу PBI серед дітей. Ми допустили, що

\begin{tabular}{|c|c|c|c|c|}
\hline Параметр & Символ & Значення & Примітка & Джерело \\
\hline Народжуваність & $\mathrm{b}$ & 1370 дітей /день & - & [12] \\
\hline Тривалість симптомів & $1 / \gamma$ & 5 днів & $\begin{array}{c}\text { Симптоми тривають протягом } 2-7 \\
\text { днів (в середньому } 5 \text { днів) }\end{array}$ & [17] \\
\hline $\begin{array}{c}\text { Ймовірність } \\
\text { сприйнятливості після } \\
\text { n-го випадку } \\
\text { захворювання на РВI }\end{array}$ & $\alpha_{n}$ & $\begin{array}{ll}\mathrm{n}=1: & 0,62 \\
\mathrm{n}=2: & 0,65 \\
\mathrm{n}=3 ; & 0,85\end{array}$ & $\begin{array}{c}\text { Ймовірність сприйнятливості - } \\
62 \%, 65 \% \text { та } 85 \% \text { після } 1,2 \text { та } 3 \\
\text { попередніх випадків } \\
\text { захворювання відповідно }\end{array}$ & [14] \\
\hline $\begin{array}{c}\text { Ймовірність } \\
\text { виникнення симптомів } \\
\text { при n-тому випадку } \\
\text { захворювання на РВI }\end{array}$ & $\xi_{\mathrm{n}}$ & $\begin{array}{ll}\mathrm{n}=1: & 0,47 \\
\mathrm{n}=2: & 0,25 \\
\mathrm{n}=3: & 0,32 \\
\mathrm{n}=4: & 0,20\end{array}$ & $\begin{array}{c}\text { Частка осіб, що захворіли на n-ий } \\
\text { випадок захворювання на РВI } 3 \\
\text { проявом симптомів відповідно }\end{array}$ & [14] \\
\hline $\begin{array}{c}\text { Швидкість переходу } 3 \\
\text { групи } i \text { в групу } i+1 \\
\end{array}$ & $\delta$ & $1 / 365$ & - & - \\
\hline $\begin{array}{c}\text { Швидкість зниження } \\
\text { імунітету після } \\
\text { перенесеної РВI }\end{array}$ & $\omega_{1}$ & $\begin{array}{c}0,0000637 \\
\text { (1/43 роки в перерахунку } \\
\text { на } 1 \text { день); } \\
\text { отримано шляхом } \\
\text { наближення моделі до } \\
\text { даних досліджень }\end{array}$ & $\begin{array}{c}\text { Швидкість, з якою імунні особи } \\
\text { стають сприйнятливими до } \\
\text { наступних випадків захворювання }\end{array}$ & - \\
\hline $\begin{array}{l}\text { Ймовірність } \\
\text { інфікування }\end{array}$ & $\lambda_{\mathrm{i}}(\mathrm{t})$ & $\begin{array}{l}\text { Отримано шляхом } \\
\text { наближення моделі до } \\
\text { даних досліджень }\end{array}$ & $\begin{array}{c}\text { Доля контактів між хворою та } \\
\text { здоровою дитиною, що } \\
\text { призводить до інфікування (індекс } \\
\text { контагіозності) }\end{array}$ & - \\
\hline
\end{tabular}

Таблиця 1. Параметри моделі та їх значення

всі діти мали певний рівень пасивного імунітету при народженні, який зменшувався з певною швидкістю, після чого особи переходили до групи сприйнятливих осіб до інфікування 1 випадком РВІ з постійною швидкістю, яка дорівнює народжуваності в Україні $\mathrm{b}=1370$ дітей в день [12]. Діти усіх вікових груп, сприйнятливих до 1 -4 випадку захворювання, можуть бути інфіковані з ймовірністю 1(1), яка має сезонний характер [13], та одужують після інфекції зі швидкістю у. На основі літературних даних ми дійшли до вис- новку, що необхідно розглядати принаймні три випадки повторного інфікування (чотири класи сприйнятливості) [14]. Ймовірність сприйнятливості дитини складає $\left(\mathrm{aj}_{3}\right)$ після кожного $з$ трьох випадків PBI, а частка осіб, які, набувають імунного захисту після кожного інфікування (1-a $\left.\mathrm{a}_{13}\right)$, змінюється залежно від кількості попередньо перенесених випадків інфекцій. На основі даних, одержаних Velasquez та співавт. і підтверджених іншими авторами [14-16], ми припустили, що ймовірність сприйнятливості після n-го ви- 
падку захворювання на РВІ складає 62 \% після першого випадку, $65 \%(=0,40 / 0,62)$ після другого випадку та $85 \%(=0,34 / 0,40)$ після третього випадку захворювання. Після чотирьох випадків захворювання всі особи ставали імунними та переходили до класу осіб, що одужали. Крім того, ми припустили, що 47 \% від кількості випадків першого, 25 \% - другого, 32 \% - третього та $20 \%$ - четвертого випадків інфікування мають перебіг з клінічними проявами. Зазвичай симптоми тривають від 2 до 7 днів, в середньому 5 днів [17]. Захворювання завершується видужанням дитини, або менш ймовірним летальним наслідком. Перейшовши до групи дітей, які одужали, діти вважаються тимчасово імунними до повторних випадків захворювання. Набутий імунний захист знижується зі швидкістю $\mathrm{a}_{1}$ та згодом особи переходять до класу сприйнятливості до 4 випадку інфекції, якою вони можуть бути інфіковані з ймовірністю Я(1). Тому ми припустили, що діти, у яких розвивається протиротавірусний імунітет внаслідок 1, 2, 3 або 4 випадків захворювання, мають менші ймовірності в майбутньому захворіти на РВI. Швидкість зниження протиротавірусного імунного захисту $\mathrm{a}_{1} \epsilon$ невизначеним параметром, тому значення $a_{1}$ було розраховано шляхом наближення моделі до експериментальних даних клініко-лабораторних спостережень за РВI в Україні.

Ймовірність інфікування ІД) залежить від контактів сприйнятливих осіб з хворими особами або вірусоносіями, а також від шляхів та чинників передачі інфекції, що є відсотком контактів між сприйнятливими та інфікованими особами, які призводять до нових випадків інфекційного захворювання.

Нами розраховане оптимальне наближення моделі до даних клініко-лабораторних спостережень за РВI серед дітей віком від одного до п'яти років, хворих на ГКІ вірусної етіології. Для апроксимації ми вико ристали програмне забезпечення Маїьсад 15.

Оскільки функція, що описує сезонність PBI у часі, $\epsilon$ періодичною, то було доцільно апроксимувати отримані експериментальні дані функцією вигляду:

$$
Y(t)=A(1-\cos (2 \pi t / 365-\varphi))^{n} / 2^{n}
$$

$$
\begin{aligned}
& Y(t)=0,854(1-\cos (2 \pi t / 365- \\
& -91.052))^{15.403} / 2^{15.403}
\end{aligned}
$$

$$
\begin{aligned}
& \lambda_{i}(t)=\lambda_{\max _{-} i}(1-\cos (2 \pi t / 365- \\
& -91.052))^{15.403} / 2^{15.403}, \\
& \lambda_{\max i=} \lambda_{\max } \\
& \lambda_{\max _{-} i}(i)=\frac{-\ln \left(1-p_{\max i}(i)\right)}{365} \\
& \text { де } p(i) . \\
& \lambda_{\text {max }}
\end{aligned}
$$

Таблиця 2. Максимальні значення ймовірності інфікування $1_{\text {тах }}$. для 7-ї вікової групи

\begin{tabular}{|c|c|c|}
\hline Вікова група, $i$ & Частота виявлення РВ, $p(i)$ & $\begin{array}{c}\text { Амплітуда сезонної ймовірності інфікування } \lambda_{\max \_ \text {для }} \\
\text { кожної вікової групи } a \text { в перерахунку на } 1 \text { день як } \\
\text { одиницю часу }\end{array}$ \\
\hline$<1$ року & 0,01041 & 0,000029 \\
\hline 1 рік & 0,40625 & 0,001381 \\
\hline 2 роки & 0,66667 & 0,000826 \\
\hline 3 роки & 0,80208 & 0,000399 \\
\hline 4 роки & 0,88542 & 0,000238 \\
\hline 5 років & 0,90625 & 0,000058 \\
\hline
\end{tabular}


Ми припустили, що кількість новонароджених (діти, які входять до складу наймолодшої вікової групи) та кількість осіб, що залишають найстаршу вікову групу) була рівною, таким чином загальний розмір популяції залишався сталим.

\section{Результати моделювання.}

В результаті дослідження моделі в пакеті прикладних програм MaІiab 2009а було отримано модель епідемічного процесу PBI серед дітей в Україні (рис. 1). Оскільки при вирішенні даної задачі були відсутні початкові дані, модель було отримано за їх відсутності шляхом насичення системи до рівня, на якому система стабілізується та в ній не встановлюється стаціонарний вимушений коливальний процес. Такий підхід виявився слушним, оскільки отримані модельні сезонні коливання збігаються з апроксимованими даними клініко-лабораторних спостережень сезонності РВІ в Україні (рис. 1).

При розгляді моделі за кількістю перенесених випадків PBI, домінує група дітей 31 випадком захворювання (рис. 2).

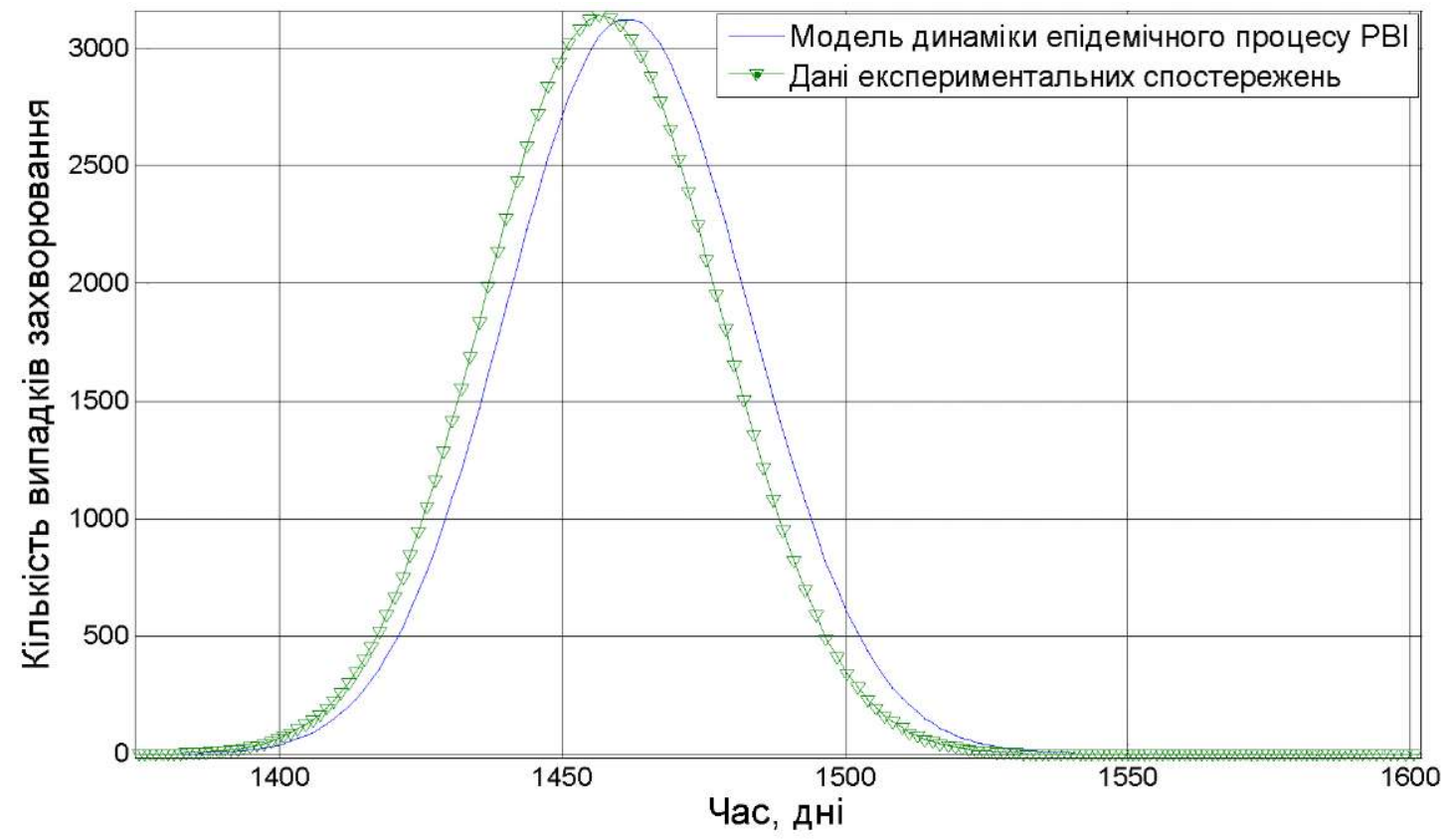

Puc. 1. Модель динаміки епідемічного процесу PBI: сумарна кількість випадків захворювання на PBI за усіма віковими групами (1-5 років) та за кількістю перенесених (1-4) випадків.

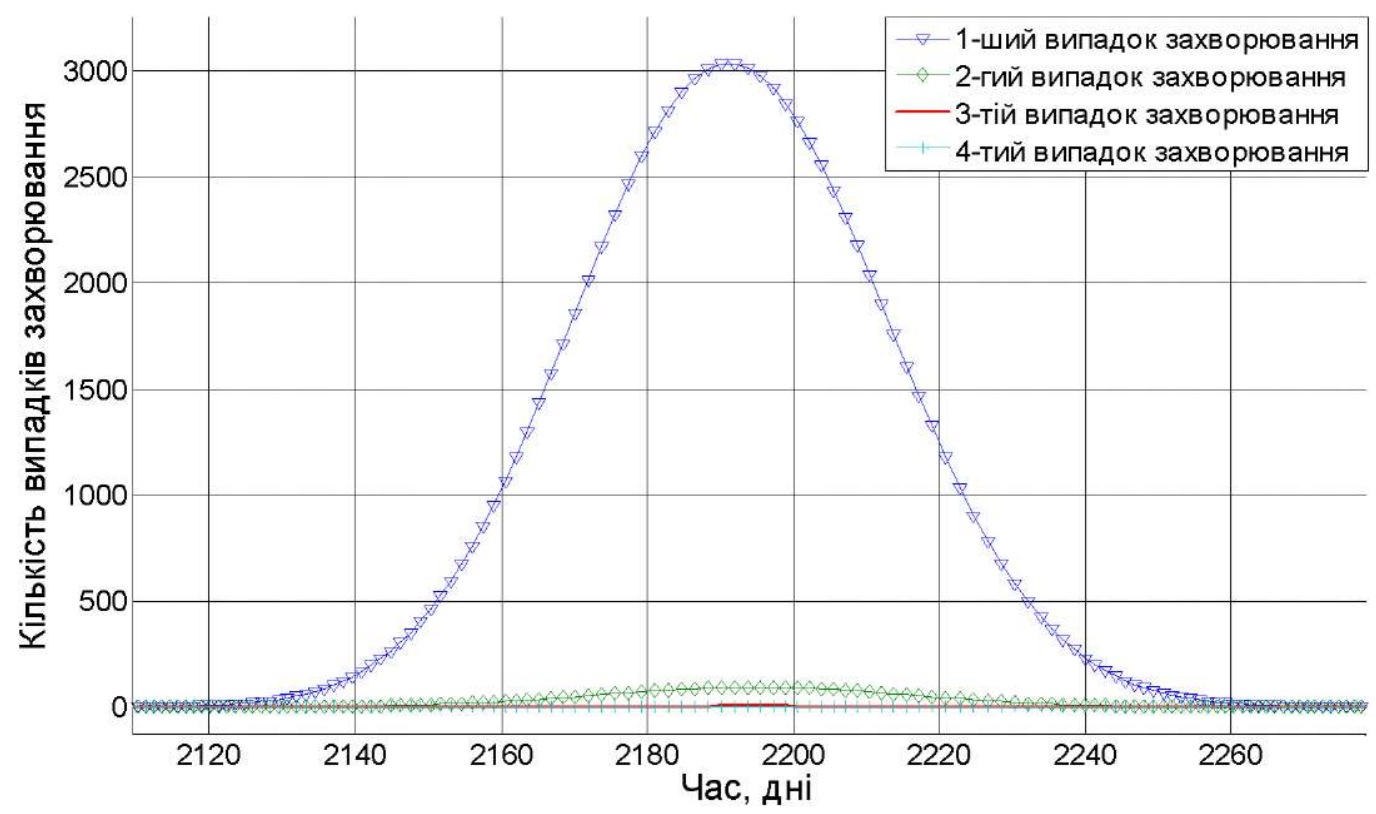

Puc. 2. Модель динаміки епідемічного процесу РВІ за кількістю попередньо перенесених випадків захворювання $\mathrm{Y}_{\mathrm{n}}(\mathrm{n}=1-4)$. 
Проведений аналіз моделі динаміки захворюваності на PBI за окремими віковими групами виявив наступну закономірність домінування окремих вікових груп в епідемічному процесі PBI: "1 рік" > "2 роки" > "3 роки" = "4 роки" > "5 років" > "<1 року" (рис. 3).

В нашому дослідженні ми вважаємо, що приріст населення в одиницю часу є постійним. Це має сенс, оскільки за даними Держкомстату України народжуваність в Україні сягає близько 500 тис. осіб на рік [7]. Однак для дослідження впливу демографічних змін ми припустили, що такий приріст буде збільшуватись на 5 \% щорічно. Показано, що досліджувана модель значною мірою залежатиме від коливань народжуваності в Україні (рис. 4).

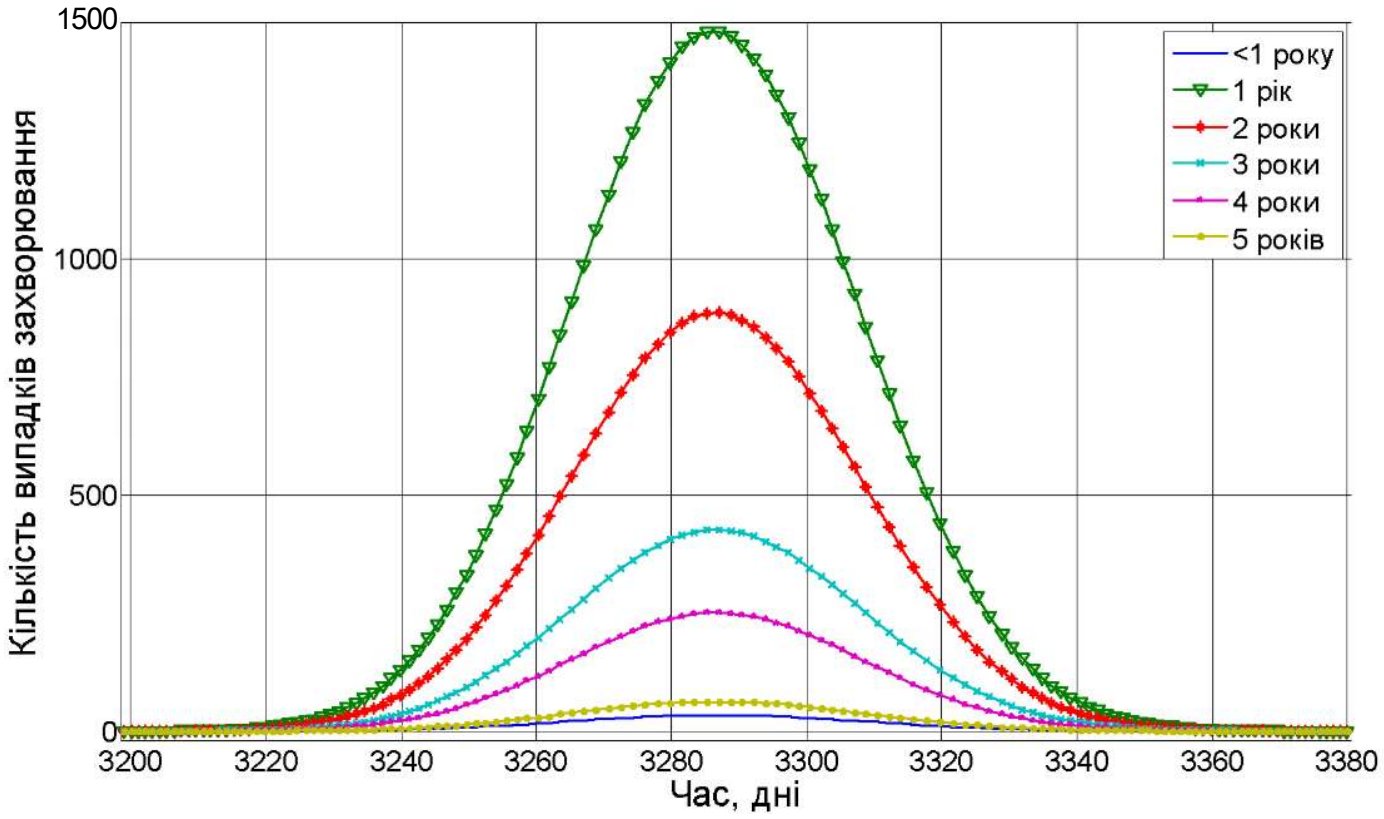

Puc. 3. Модель динаміки епідемічного процесу РВІ за окремими віковими групами У (i=1-6).

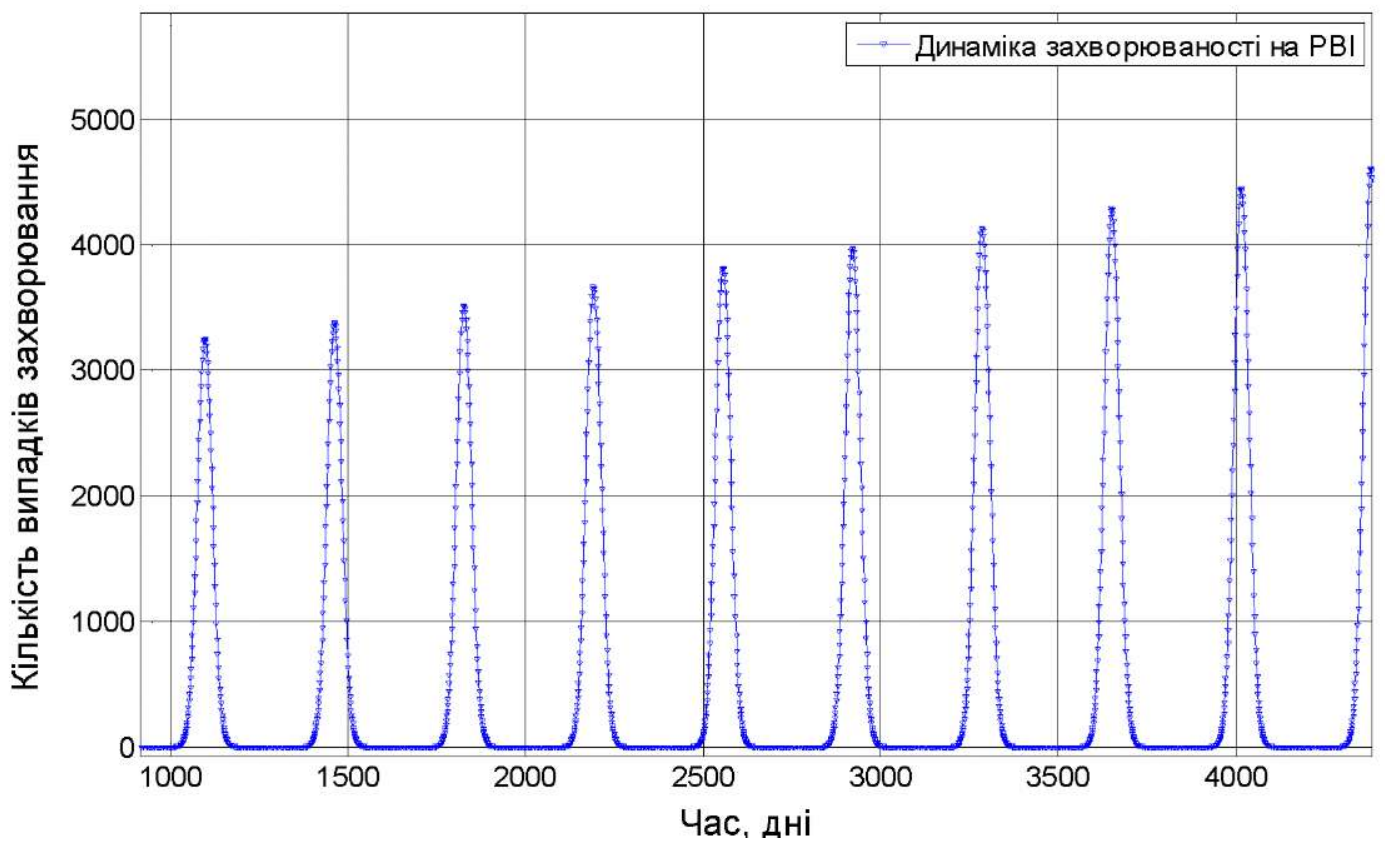

Висновки. В результаті дослідження було проведено ретроспективний епіміологічний аналіз захворюваності на РВI. На основі власних клініко-лаборатор- них спостережень та даних літератури встановлено базові особливості епідемічного процесу РВI серед дітей в Україні та побудовано модель його річної та 
багаторічної динаміки. Вивчено розподіл випадків захворювання за окремими віковими групами та залежно від кількості попередньо перенесених випадків захворювання на РВI. Показано, що в структурі епідемічного процесу РВI домінує кількість випадків першого захворювання, та вікова група "1 рік". Результати показали, що досліджувана модель значною мірою за-

\section{Лiтература}

1. Марченко Б. И. Метод вероятностного моделирования эпидемического процесса вирусного гепатита А. В: Социально-гигиенический мониторинг - практика применения и научное обеспечение // Марченко Б. И. - М., 2000. - С. 75-79.

2. Мефодьев В. В. Прогнозирование заболеваемости брюшным тифом в регионе северных новостроек/ Мефодьев В. В. // Журн. микробиол. - 1988. - №> 12. - С. 81-84.

3. Власов В. И. Метод краткосрочного прогнозирования годовых показателей заболеваемости дизентерией вида Зонне / В. И. Власов, Б. А. Замотин, В. М. Бурых // Журн. микробиол. - 1983. №> 3. - С. 53-56.

4. Сергиев В. П. Расчет тенденций заболеваемости брюшным тифом на разных территориях страны / В. П. Сергиев, В. Н. Никонова // Журн. микробиол. - 1980. - №> 10. - С. 1417.

5. Боев Б. В. Современные этапы математического моделирования процессов развития и распространения инфекционных заболеваний / Б. В. Боев // Эпидемиологическая кибернетика: модели, информация, эксперименты. - М., 1991. - С. 6-13.

6. Статистическая модель эпидемического процесса / Бородулин А. И., Десятков Б. М., Шабанов А. Н., Ярыгин А. А. // Сибирский журнал индустриальной математики. - 2007. - T. 10, №> 2. - C. 23-30.

7. Бароян О. В. Математика и эпидемиология / О. В. Бароян, Л. А. Рвачев - М. : Знание, 1977. - С. 63.

8. Бароян О. В. Прогнозирование эпидемий гриппа в условиях СССР // О. В. Бароян, Л. А. Рвачев // Вопросы вирусологии. - 1978. - №> 2. - С. 131-137.

9. Бароян О. В. Моделирование и прогнозирование эпидемий гриппа для территории СССР / О. В. Бароян, Л. А. Рвачев, Ю. Г. Иванников - М. : ИЭМ им. Н.Ф. Гамалеи, 1977. - лежатиме від коливань народжуваності в Україні. Розроблена модель може бути використана в подальшому для вивчення впливу різних факторів, в тому числі i вакцинації, на захворюваність PBI, експертами та спеціалістами установ охорони здоров'я при вирішенні задач, направлених на запобігання виникненню спалахів та епідемій РВІ в Україні.

C. 546.

10. Соловйов С. О. Математичне моделювання як сучасний інструмент прогнозування ефективності протиротавірусних вакцин / С. О. Соловйов // Медична інформатика та інженерія. - 2011. - № 2. - С. 59-63.

11. Соловйов С. О. Побудова й аналіз моделі прийняття рішень при оцінці наслідків вакцинації протиротавірусною вакциною в Україні / С. О. Соловйов, І. В. Дзюблик // Медична інформатика та інженерія. - 2011. - № 4. - С. 42-49.

12. Державний Комітет Статистики України www.ukrstat.gov.ua

13. Shkedy Z. Flexible Statistical Modelling: Application to Infectious Diseases and Astronomical Data. Ph.D. thesis, Limburgs Universitair Centrum, 3590 Diepenbeek, Belgium.

14. Rotavirus infections in infants as protection against subsequent infections / F. R. Velazquez, D. O. Matson, J. J. Calva [et al.] // N. Engl. J. Med. - Vol. 335. (1996), - P. 10221028.

15. Protection conferred by neonatal rotavirus infection against subsequent rotavirus diarrhea / M. K. Bhan, J. F. Lew, S. Sazawal [et al.] // J. Infect. Dis. - 1993. - Vol. 168. - P. 282-287.

16. Ruiz-Palacios G. Safety and efficacy of an attenuated vaccine against severe rotavirus gastroenteritis / G. RuizPalacios, I. P. Schael, F. Velazquez// N. Engl. J. Med. - 2006. Vol. 354. - P. 11-22.

17. Heymann D. L. Gastroenteritis / D. L. Heymann // Control of Communicable Diseases Manual, (18th ed.), American Public Health Association (2004), P. 224-227.

Public health impact and cost effectiveness of mass vaccination with live attenuated human rotavirus vaccine (RIX4414) in India: model based analysis / J. Rose, R. L. Hawthorn, B. Watts, M. E. Singer// BMJ. - 2009. - Vol. 339. P. 3653. 